\title{
Heart Rate Monitoring and Stimulation with the Internet of Thing-Based (IoT) Alquran Recitation
}

\author{
Dirja Nur Ilham ${ }^{1}$ \\ Politeknik Aceh Selatan \\ Tapaktuan, Aceh-Indonesia \\ dirja@poltas.ac.id \\ Balkhaya $^{3}$ \\ Politeknik Aceh Selatan \\ Tapaktuan, Aceh-Indonesia \\ balkhaya@poltas.ac.id
}

\author{
Hardisal $^{2}$ \\ Politeknik Aceh Selatan \\ Tapaktuan, Aceh-Indonesia \\ hardisal@poltas.ac.id \\ Rudi Arif Candra ${ }^{4}$ \\ Politeknik Aceh Selatan \\ Tapaktuan, Aceh-Indonesia \\ rudicandra@poltas.ac.id
}

\author{
Erwinsyah Sipahutar \\ Politeknik ATI Padang \\ Padang, Sumatra Barat-Indonesia \\ erwin.metro@yahoo.co.id
}

\begin{abstract}
Heart rate or pulse is an important parameter used to determine a person's mental state because when the heartbeat is abnormal, it is necessary to make further efforts to prevent undesirable things from happening. In this study, researchers plan to design the Heart Rate Monitoring and Stimulation with the Internet of Thing-Based (IoT) Qur'an Recitation. The steps taken to design a monitoring system and stimulate the human heartbeat are to design hardware and software. The sensor used is a pulse heart rate sensor as a heart rate detector processed by Arduino-based NodeMCU V3, the test results and measurements will be sampled using smartphone media. Data collection process; polytechnic students as objects taken by their heart rate data, the data collection process was carried out twice, the morning before the lecture began and the afternoon after the lecture process was complete, the testing process was done by taking data using a smartphone and turning on the Quran recitation for 2 minutes. Research is expected to be an stimulus indicator of heart rate, so that the heart rate is more relaxed and calm.
\end{abstract}

Keywords - IOT, Heart Monitoring, Stimulation, Alquran Recitation

\section{INTRODUCTION}

Murottal is a recorded voice of the Quran recited by a qori (reader of the Koran), murottal can be interpreted as chanting verses of the Quran read to the rhythm by a qori, recorded and played with a slow and harmonious tempo. Murottal is one of music that has a positive influence on the listener. The Koran that is recited in a tartil and correct way will bring peace of mind. Heart rate or pulse is an important parameter used to determine a person's mental state because if the heartbeat is abnormal then further efforts need to be made to prevent the desired things from happening. As is known heart disease is one of the highest causes of death in the world.

Stethoscope is a device used to measure heart rate. This tool is simple and easy to carry but has a weakness that must be checked repeatedly and requires concentration to calculate the heart rate. In addition, the device is only owned by paramedics and when someone wants to check the heartbeat, it must be done by doctors and health workers. The constraints of mobility and accuracy are the basis in the design of this tool.

Research on the use of heart rate sensors has been widely carried out by researchers, such as that of 
(Murthi \& Haryanto, 2014), Design of Heartbeat Measuring Devices and Human Body Temperature using ATmega 16 Microcontroller, (Suryana \& Aziz, 2017), Lamp Control Devices with IoT Technology, (Candra, Nur Ilham, Hardisal, \& Sriwahyuni, 2019), Heart Rate Monitor with Three Sensors or research by (Sulistyo, 2016) Arduino-based pulse rate detection devices that are interfaced to a computer. All studies have not used the Internet of things (IoT) and are portable. (Goel, Srivastava, Pandit, Tripathi, \& Goel, 2018) research with the title Heart-rate monitoring system using finger tip through IOT obtained results of heart rate sensor monitoring data using IOT from finger print, normal 60-70 normal and 90 abnormal. According to (Nafi'ah, Zakiyatun, Maliya, \& Dewi, 2016) there is the influence of Murottal Alquran on the blood pressure and heart rate frequency. (Afandi, Ferdiana, \& Nugroho, 2014) music can provide relaxation in the process of human heart rate.

\section{RESEARCH METHODOLOGY}

The following is a flowchart of the tool design procedure. As in Figure 1.

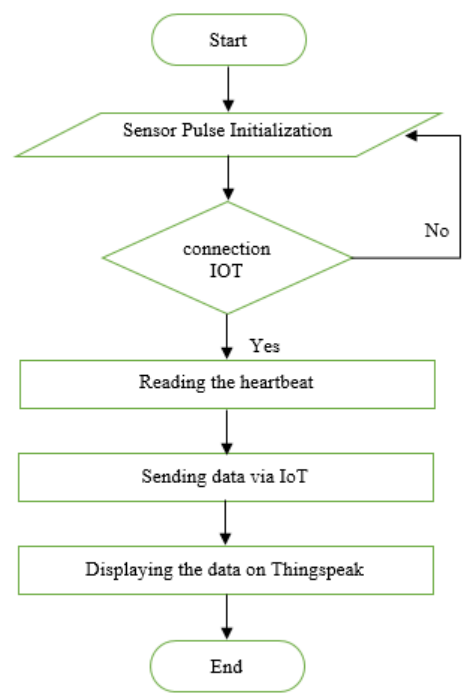

Figure 1. Program Flowchart

From Figure 1 above it can be seen that when the system starts and then the program input is carried out, the Pulse sensor will send data, if not, then the program input is repeated. If yes, then it is processed using IoT (Internet of Things). The data released is processed or sent to the Thingspeak Application as output on this tool, complete.

\section{IMPLEMENTATION}

\section{Pulse Sensor Series to NodeMCU}

Signal pins on the Pulse Sensor are connected to pin A0 on NodeMCU, GND pin on Pulse Sensor to GND pin on NodeMCU and VCC pin on Pulse Sensor are connected to pin $3 \mathrm{~V} 3$ on NodeMCU. As shown in Figure 2.

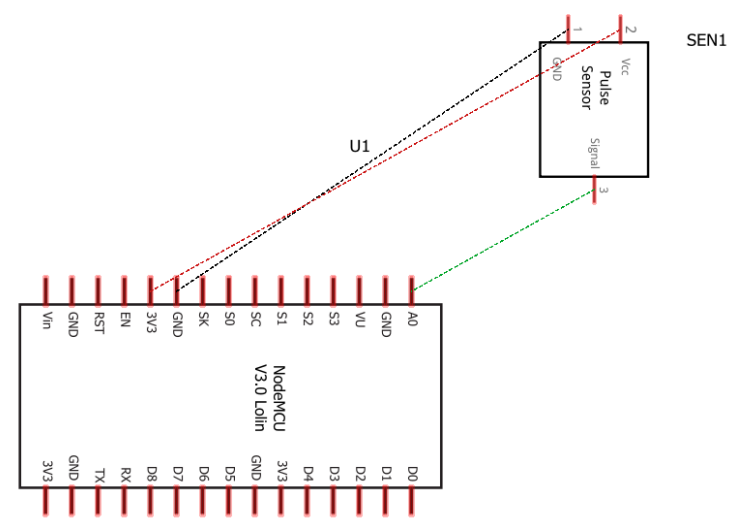

Figure 2. Results of the Pulse Sensor Series to NodeMCU

\section{Thingspeak Application Series}

Thingspeak has a close relationship with Mathworks, Inc. In fact, all Thingspeak documentation is posted on the Matlab documentation website; Mathworks and even allows Mathworks users to log in validly on the Thingspeak site. Termspeak.com's terms of service and privacy policy are the same as Mathworks, Inc.

Register and Sign In to http://thingspeak.com

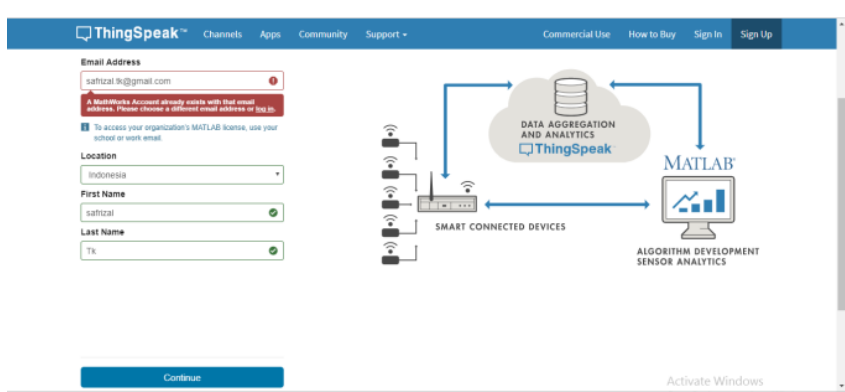

Figure 3. Results of the Thingspeak Registration Series

\section{Establishing Data Channels}

Click New Channel to create a Data Channel. Fill in the required fields (one channel a maximum of 8 filed). Fill in the channel name ('Name') and field1 (check the 'Make Public' option) if you want data from Thingspeak to be seen by many people. This field will later contain sensor data sent from Arduino 
and ESP8266. After completing data, press Save Channel).

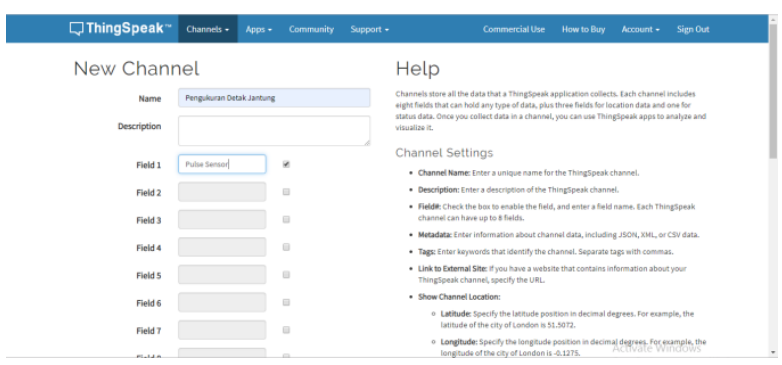

Figure 4. Results of Thingspeak Channel Data Series

Thingspeak Channel Display

The following is a display of IoT heart rate measurements on the previously made Thingspeak channel

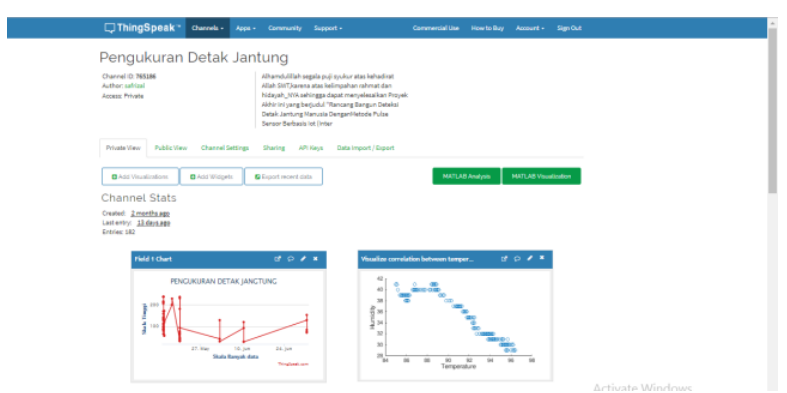

Figure 5. Results of Thingspeak Channel Interface

saving API Key into sketch NodeMCU.

To get the Write Data Access Key through the API Key menu then copy the Key in the Write API Key section. Whereas the Key Read API Key is used to read data. Channel ID will be used to display data through the android application.

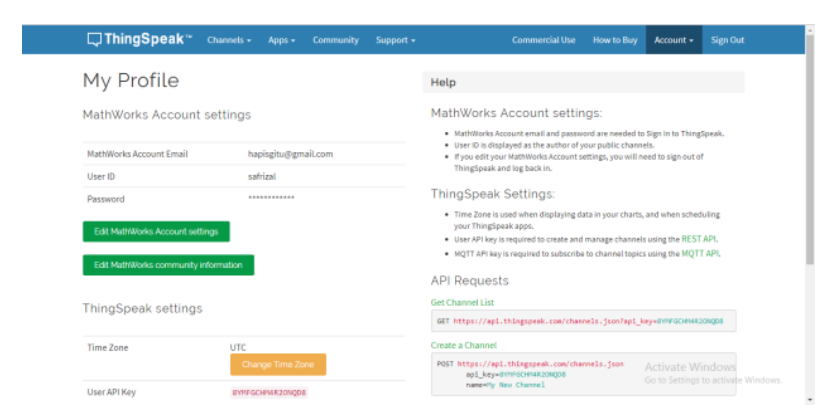

Figure 6. API Key Thingspeak Series
The results of the experiment are displayed to the Thingspeak application. By using IoT (Internet of Things), the results of the experiment can be viewed graphically as applied to Thingspeak as shown in Figure 7.

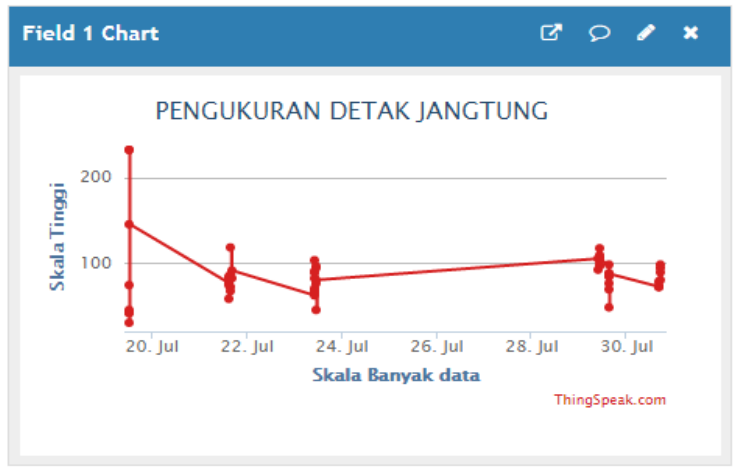

Figure 7. Heart rate measurement results

\section{Testing Modul ESP8266}

At this stage the WiFi module testing, ESP8266, is performed on the hardware. This test is conducted to determine whether the software is able to communicate and receive data properly from the hardware. The test is done by entering several commands into the module via serial communication using the SM (Serial Monitor) command. This command can be seen in Figure 8.

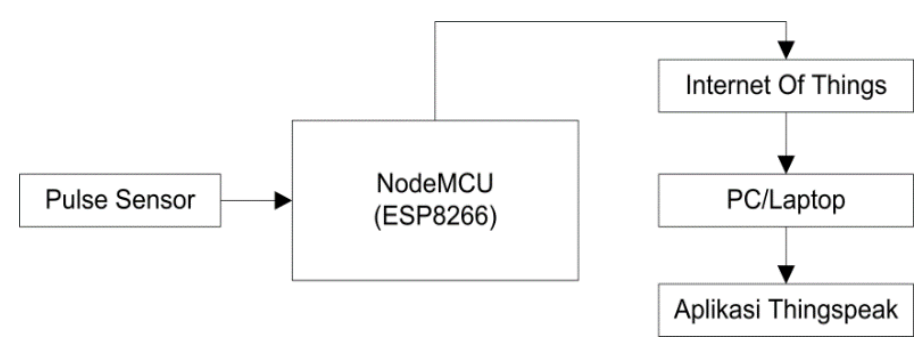

Figure 8. Testing modul ESP8266

\section{Testing Data Sending to Thingspeak}

The appearance of Thingspeak application is done to monitor data remotely so that Hospital operators can continue to monitor the condition of patients who have heart disease. Thingspeak cloud testing aims to review the discharge on the patient's condition. After the data is stored on the Thingspeak web server. 


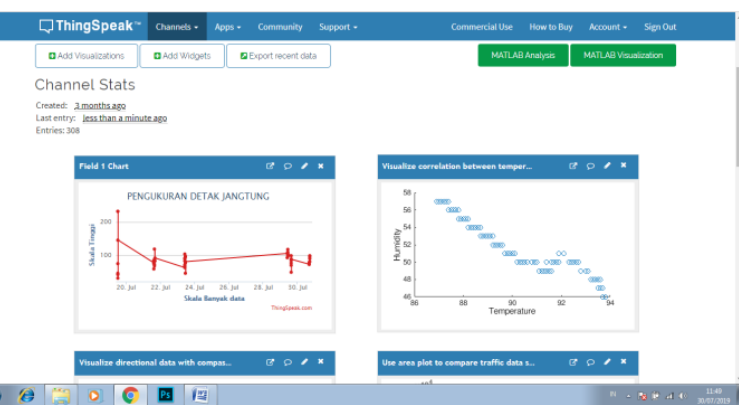

Figure 9. Testing Thingspeak Application

\section{System Functional Testing}

The purpose of functional testing of this system is to test the overall features that exist in this system. In this system will be tested from a heart rate reading sensor, the system sends data to thingspeak. Testing procedures in the functional testing of the system, i.e:

1. Use a prototype system on the human arm.

2. Turn on the hotspot on the smartphone.

3. Open the thingspeak application, fill in the ID channel.

4. See the results of the sensor readings in the thingspeak application.

5. See the results of heart rate measurements.

6. Observing if there are BPM less than 80 or more than 150 .

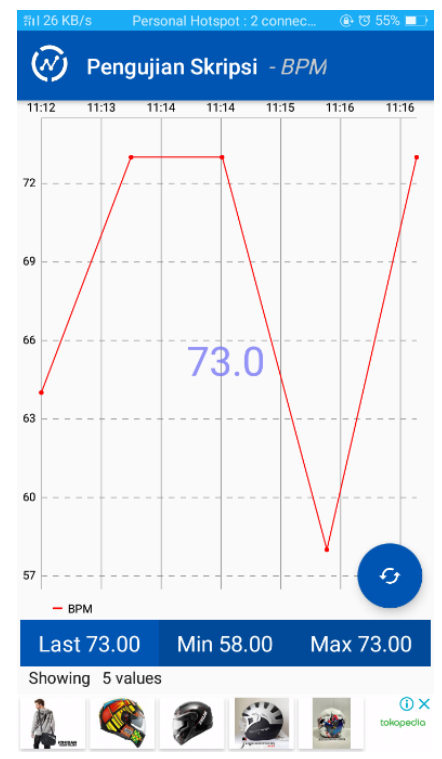

Figure 10. System Functional Testing

\section{CONCLUSION}

After making a tool to monitor heart rate using the Thingspeak application based on the internet of things, and then testing the heart rate of South Aceh
Polytechnic students both using a test tool and by manual, then it can be concluded:

1. The design of a heart rate monitor utilizes IOT (Internet of Things) to make it easier to see the human heartbeat clearly in the Thingspeak application.

2. Devices that are made can work as tools when connected to the internet using a cellular hotspot.

3. A heart rate monitoring tool that works well can be proven by testing and the results that appear in the Thingspeak application.

Based on testing, a heart rate monitoring tool will give results within 60 seconds after the examination.

\section{REFERENCES}

Afandi, I. K., Ferdiana, R., \& Nugroho, H. A. (2014). Review: Musik dan Denyut Jantung Pada Era Digital. JSINBIS (Jurnal Sistem Informasi Bisnis), 149-155. doi:10.21456/vol4iss3pp149-155

Candra, R. A., Nur Ilham, D., Hardisal, H., \& Sriwahyuni, S. (2019). Light Control Design by Using Social Media Telegram Applications Based on Internet Of Things (IOT). SinkrOn, 200-204.

Goel, V., Srivastava, S., Pandit, D., Tripathi, D., \& Goel, P. (2018). Heart Rate Monitoring System Using Finger Tip through IOT. International Research Journal of Engineering and Technology (IRJET), (pp. 1114-1117). Utter Pradesh.

Murthi, W. A., \& Haryanto, H. (2014). RANCANG BANGUN ALAT UKUR DETAK JANTUNG DAN SUHU TUBUH MANUSIA BERBASIS MIKROKONTROLER ATMEGA16. Go Infotech, 18-24.

Nafi'ah, N., Zakiyatun, R., Maliya, A., \& Dewi, E. (2016). Pengaruh Terapi Murottal AlQuran Terhadap Tekanan Darah Dan Frekuensi Denyut Jantung Pasien Pasca Operasi Dengan Anestesi Umum Di Rumah Sakit Umum Daerah Dr. Moewardi Surakarta. Surakarta: Universitas Muhammadiyah Surakarta.

Sulistyo, E. (2016). ALAT PENDETEKSI DENYUT NADI BERBASIS ARDUINO YANG DIINTERFACEKAN KE KOMPUTER. 
Semnastek (pp. 1-4). Jakarta: Fakultas Teknik Universitas Muhammadiyah Jakarta. Suryana, Y., \& Aziz, R. (2017). Sistem Pemonitor Detak Jantung Portable Menggunakan Tiga
Sensor Elektroda. Jurnal Ilmiah Al-Azhar Indonesia, 14-17. 